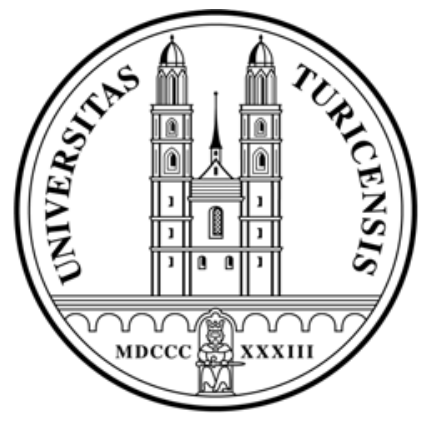

Institute for Empirical Research in Economics

University of Zurich

Working Paper Series

ISSN 1424-0459

Working Paper No. 394

\title{
A Behavioral Account of the Labor Market: The Role of Fairness Concerns
}

Ernst Fehr, Lorenz Goette and Christian Zehnder

November 2008 


\title{
A Behavioral Account of the Labor Market: The Role of
}

\author{
Fairness Concerns*
}

\author{
Ernst Fehr ${ }^{\dagger}$, Lorenz Goette ${ }^{\ddagger}$ and Christian Zehnder ${ }^{\S}$
}

November 2008

\section{Forthcoming in: Annual Review of Economics 2009}

\begin{abstract}
In this paper, we argue that important labor market phenomena can be better understood if one takes (i) the inherent incompleteness and relational nature of most employment contracts and (ii) the existence of reference-dependent fairness concerns among a substantial share of the population into account. Theory shows and experiments confirm, that even if fairness concerns were only to exert weak effects in one-shot interactions, repeated interactions greatly magnify the relevance of such concerns on economic outcomes. We also review evidence from laboratory and field experiments examining the role of wages and fairness on effort, derive predictions from our approach for entry-level wages and incumbent workers' wages, confront these predictions with the evidence, and show that referencedependent fairness concerns may have important consequences for the effects of economic policies such as minimum wage laws.
\end{abstract}

\footnotetext{
* We are very grateful to valuable comments received from Daron Acemoglu, Charles Bellemare, Andrew Clark, Thomas Dohmen, Rafael Lalive, Bentley MacLeod, James Malcomson and Rudolf Winter-Ebmer.

${ }^{\dagger}$ Institute for Empirical Research in Economics, University of Zurich. Email: efehr@iew.uzh.ch

${ }^{\ddagger}$ Federal Reserve Bank of Boston, Center for Behavioral Economics and Decision Making. Email: Lorenz.goette@bos.frb.org

$\S$ Faculty of Business and Economics (HEC), Department of Economics. Email: christian.zehnder@unil.ch
} 


\section{Introduction}

In this paper, we argue that the institutional and psychological assumptions inherent in the standard competitive model of the labor market often lead to a distorted view of the workings of labor markets. Several facts about labor markets are at odds with the competitive model. For instance, the standard model has a hard time explaining why labor market conditions have little effect on incumbent workers’ wages, why nominal wages are downwardly rigid, and why labor market conditions upon entering a firm can have long-lasting effects on workers' pay. Although these facts have important consequences for labor market outcomes, the competitive view of the labor market remains surprisingly persistent and continues to play a dominant role. The standard model in economics also assumes that all actors have preferences defined solely over the level of their own consumption; experimental research, however, has shown this assumption to be problematic in many circumstances. Many individuals are willing to sacrifice some of their own consumption to restore fairness. Furthermore, utility, and in particular, the effects of fairness perceptions on utility, are typically referencedependent, as we discuss in the next section.

The standard model of the competitive labor market relies on the assumption of well-specified and complete employment contracts, while real-life employment relationships are often characterized by incomplete contracts in which many dimensions of the interaction between employer and worker are left unspecified. In particular, effort is typically not contractible, meaning that the generation of a sufficiently motivated work force is key for a firm's productivity. As a first reaction, one might think that this should imply that pay for performance is wide-spread. However, as we will discuss in more detail later on, the effective usage of explicit incentives are limited to a narrow set of occupations. Evidence shows that apart from the upper levels of the firm's management, only few employees face explicit performance incentives and fixed hourly wages and monthly salaries are very common. In a static model, this implies that the only motivator firms use is to treat workers well and to count on their preference for fairness to reciprocate the favor. This is in line with the well documented empirical fact that managers often stress that "workers have many opportunities 
to take advantage of employers so that it is not wise to depend on coercion and financial incentives alone as motivators. [...] Employers believe that other motivators are necessary, which are best thought of as having to do with generosity" (Bewley 1995).

However, many people doubt that relying on a taste for fairness in workers is enough to overcome the motivational problem incomplete employment contracts pose. We review evidence from many laboratory and field experiments indicating that this doubt is justified. While most studies confirm that many subjects are willing to work harder if they are paid a generous wage rent, the results also show that this effect is limited in one-shot interactions and that a substantial share of the subjects provides little effort in this case. As a consequence, the positive impact of fairness concerns on performance in one-shot employment situations still leaves effort far below the efficient level.

This brings us to a second important feature of labor markets, which the competitive model also neglects: employment relationships are hardly ever spot market transactions where trading partners interact only once. Rather, employers and workers have the option of interacting repeatedly with each other. The fact that many employment relationships are characterized by long-term relations greatly amplifies the importance of fairness preferences. Game theoretic models of reputation formation show that strictly selfish individuals have an incentive to mimic fair-minded persons in a repeated setting and to exert high effort when offered a non-competitive wage rent, because this guarantees more rents in the future. Shirking, in contrast, reveals that the individual is egoistic. Firms are unwilling to pay wage rents to selfish workers once they have proven they don't reciprocate generous treatment with high effort. In fact, even the presence of a small share of fair-minded workers in a dynamic environment with repeated interactions can have a large positive impact on performance. This reputation based mechanism can be tested explicitly in laboratory experiments and proves to be very powerful: if subjects in the role of employers and employees are allowed to enter finitely repeated interactions, a large effort increase occurs, but market interactions deviate systematically from competitive predictions. 
The existence of fair-minded workers can also explain another frequently observed phenomenon in the labor market which is hard to reconcile with the competitive model. Ample evidence indicates that there is a sharp difference between wage dynamics in internal and external labor markets: while entry-level wages respond strongly to shocks in aggregated labor market conditions, incumbent workers’ wages are much less responsive to changes in the outside environment. This is in line with survey evidence showing that there is a shift in what workers feel entitled to as they enter a firm. Workers who are looking for a job in a new firm seem to evaluate the fairness of a firm's wage offer relative to the going wage in the labor market. Incumbent workers, in contrast, seem to assess the fairness of proposed wage changes in their ongoing employment relative to the status quo. Accordingly, new and incumbent workers may react completely differently to the same wage offer from the firm, and while the firm may adjust the new entrants’ wages to labor market conditions, it has a good reason for holding those of the incumbents constant.

Finally, the prevalence of fair-minded workers in the labor market may also have important new implications for policy. The reason is that policy measures may influence the reference point relative to which workers evaluate the fairness of their employment situation. We illustrate this possibility with one of the most wide-spread instruments of labor market interventions: minimum wage legislation. We discuss experimental evidence which shows that changes in the level of the minimum wage strongly affect what subjects perceive as the fair wage. In particular, a rise in minimum wages also raises reservation wages, implying that the effect of minimum wages on wages and employment may be very different from that which standard labor market theories predict. Furthermore, since the effects of increases and decreases in minimum wages turn out to be asymmetric, minimum wage policy may have effects that prevail even after the policy has been reverted.

We are, of course, not the first to point out the importance of fairness concerns in employment relations and labor markets. Marshall (1925; 1969) and Hicks (1932) already argued for the 
relevance of fairness concerns in wage negotiations. Likewise, authors such as Slichter (1920), Akerlof (1982) and Rees (1993) stressed such concerns. We believe, however, that the more recent work benefits from the development of game theoretic tools and experimental methods which enable us to sharpen and deepen our understanding of fairness concerns in employment settings. Without game theoretic tools it is, for example, impossible to rigorously prove the theoretical claim that even if only a minority of subjects cares for fairness, fairness concerns may nevertheless strongly shape the overall outcome. Likewise, it is hard, if not impossible, to provide rigorous evidence for such a claim without using laboratory experimental tools. Moreover, the recent wave of field experiments enabled researchers to study the potential impact of fairness concerns in natural environments. We thus hope that given these new techniques and opportunities - others will be encouraged to extend and deepen our knowledge of the role of fairness concerns in labor markets.

In the next section we will briefly describe the empirical basis of our main motivational assumptions, i.e. reference-dependent fairness preferences. In section 3, we substantiate our claim that many labor markets deviate fundamentally from the competitive model because of the inherent incompleteness and relational nature of the employment contract. We then review in section 4 the evidence of laboratory and field experiments that examine the impact of wage variations on effort. In this context, it is interesting to observe that laboratory and field evidence yield converging conclusions about the role of fairness preferences in one-shot or short-term interactions. We will also review evidence with a bearing on the role of fairness concerns in repeated interactions in this section, and will show that several important features of internal labor markets are consistent with the predictions of our approach. Finally, section 4 also discusses the claim that economic policies such as minimum wage laws may induce important shifts in the reference standards that form the basis for fairness judgments, thus causing potentially important effects on reservations wages, actual wages, and employment. 


\section{Psychological Forces}

Standard economic analysis assumes that individuals' preferences are defined only over their own economic payoffs, and that these payoffs enter the utility function in levels. However, evidence from two decades of research in experimental economics has questioned this assumption. We discuss two of the most intensively debated topics of this literature. The first concerns the assumption of selfishness, that is, that one's own consumption or economic payoff alone enters the utility function. The evidence indicates, however, that a significant share of individuals also cares about others' economic payoffs, and that the existence of heterogeneous social preferences has important behavioral effects. The second concerns the way in which economic payoffs enter the utility function. While the standard model assumes that only the level of payoffs matters, the evidence suggests that the levels are valued relative to a reference level. As we will discuss in the following sections, incorporating these two features of preferences leads to a new understanding of important labor market phenomena.

\subsection{Preferences for Fairness}

The prototypical game to test whether individuals not only care about their own payoffs, but also about their payoffs relative to those of others, is the ultimatum game, first proposed by Güth et al (1982). In the ultimatum game, a proposer can make an offer of how to divide, say, $\$ 10$ to a second party, the responder. The responder can accept or reject the offer. If he accepts, the parties receive the split the proposer offers. If the responder rejects, both parties receive nothing. A robust result in these games is that offers of less than 20 percent to the respondent are often rejected, while offers of 40 percent or more are usually accepted (Camerer 2003; Fehr \& Schmidt 2002; Roth 1995). As a consequence, many proposers make offers that are close to the equal split. These results challenge the selfishness hypothesis, because the game is played only once, meaning a strictly selfish responder should always accept any positive amount offered. A plausible interpretation for the rejection of low offers which is typically also supported by responders' verbal accounts of their behavior - is that subjects perceive them as unfair. The responder incurs a psychological cost if he or she only receives a small share when the proposer could have chosen an equitable split. If this 
psychological cost is large enough, the responder may prefer forgoing his share in order to avoid the unfair outcome.

Indications of social preferences are not limited to rejections of low offers in the ultimatum game. There exist many other (anonymously played) one-shot games in which observed behaviors cannot be reconciled with the selfishness assumption. In dictator games - a modified version of the ultimatum game in which the responder cannot reject the offer - many people transfer positive amounts although they could earn more money by keeping everything for themselves (Kahneman et al 1986). In public good games many people deviate from the dominant strategy of complete free-riding and voluntarily contribute to the public good (Ledyard 1995) and - if given the possibility - take on additional costs to punish noncontributors (Fehr \& Gachter 2000). Many trustors in trust games place resources at the disposal of a trustee in the (often correct) expectation that the trustee returns the favor and pays back (Berg et al 1995). And in gift-exchange games (which will be discussed in detail in section 4) subjects in the role of workers are frequently willing to provide higher effort than contractually enforceable if their experimental employer provides them with a generous wage rent (Fehr et al 1993). These examples not only illustrate that fairness matters in various contexts, but they also show that fairness manifests itself in different forms. Besides the retaliatory or punishing behaviors observed in the ultimatum game; a substantial share of subjects also exhibit a tendency towards altruistic choices and frequently display positively reciprocal behaviors, i.e., they respond to generous acts with generosity. However, there is an emerging consensus among experimentalists that nonselfish punishment motives are often considerably stronger than nonselfish motives to behave in altruistic or positively reciprocal manners - an asymmetry that may cause asymmetric effects of wage cuts and wage increases on workers’ behavior (Offerman 2002).

The evidence for the existence of social preferences is also not confined to student subject pools but holds in subject pools that are representative for whole countries such as Germany (Fehr et al 2003; Dohmen et al 2009), the U.S. (Naef et al 2008), and the Netherlands 
(Bellemare \& Kröger 2007; Bellemare et al 2008); it holds under stake levels of up to three months incomes (Cameron 1999; Fehr et al 2002; Slonim \& Roth 1998) and across many different cultures (Oosterbeek et al 2004; Roth et al 1991). However, it is also important to stress that the evidence shows considerable individual heterogeneity in the strength of social preferences, i.e., a significant share of individuals also exhibits fairly selfish behaviors, a fact that turns out to be important in the way social preferences affect labor market phenomena.

Various theories have been suggested for modeling this type of social preferences (Benjamin 2005; Bolton \& Ockenfels 2000; Charness \& Rabin 2002; Falk \& Fischbacher 2006; Fehr \& Schmidt 1999; Rabin 1993). While they differ in how they model the details of preferences for fairness and reciprocity, they share the important common feature that individuals with such preferences are willing to pay to reduce ostensibly unfair outcomes or to punish unfair behaviors. Some authors have argued that rejection in the ultimatum game can be reduced through sufficient experience with the game (Binmore et al 1995; Roth \& Erev 1995). In light of the procedures used in the experiments, we view such explanations as somewhat farfetched, as the consequences of rejecting an offer in the one-shot version of the ultimatum game are straightforward and easily understandable. More recently, neuroscientific studies have corroborated the view that fairness concerns and the punishment of unfair behavior are genuine expressions of preferences. A recent paper (De Quervain et al 2004) finds that reward related neural circuits are activated if subjects decide to punish unfair behavior. These neural activations even occur if subjects have to pay to punish. Thus, punishing unfair behavior is, in terms of neural circuitry, no different from spending money for buying a positively valued good. Likewise, other authors (Tabibnia \& Lieberman 2007) found stronger activation of reward related brain circuitry if subjects receive an ultimatum game offer of $\$ 5$ when the stake size is $\$ 10$ than when they receive a $\$ 5$ offer from a stake size of $\$ 30$. Thus, keeping absolute economic payoffs constant, the reward circuitry in the human brain apparently treats a fair outcome as a reward in itself. It is also interesting that diminishing the activity in the brain region most important for humans' ability for rational decision-making - the prefrontal cortex - limits subjects' ability to reject unfair offers (Knoch et al 2007; Knoch et al 2006); 
this stands in clear contrast to arguments suggesting that subjects who reject unfair offers do not understand the nature of one-shot interactions (Binmore et al. 1995). More specifically, experimentally induced reductions in the neural activation in the right dorsolateral prefrontal cortex - a brain region that is crucially involved in cognitive control of mental operations and prepotent impulses - substantially reduces rejection rates in the ultimatum game. Thus, those brain regions crucial for rational choices are also needed for making fair choices, consistent with the notion that fair choices can be perfectly rational.

\subsection{The Reference Frame of Fairness Judgments}

The evidence we reviewed so far establishes that many individuals are willing to incur costs in order to avoid unfair outcomes or punish unfair behaviors. While the simplicity of the ultimatum game obviously renders the 50/50 split a fair outcome, at least in Western cultures $^{5}$, many economic transactions may be more complicated. For example, individuals may have no choice but to make unfair offers, or changes in the economic environment may give one party a better bargaining position. How do such factors affect fairness judgments and what is their relevance for the labor market?

Falk et al (2003) provide evidence on how the economic environment can affect fairness judgments by conducting a series of ultimatum games in which they restrict the set of possible offers the proposer can make to the respondent. In some treatments, the proposer can only make unfair offers, while the proposer has a choice between unfair and fair offers in others. The evidence indicates that responders are more likely to reject the unfair offer when it was intentional, i.e., when the proposer had a choice between a fair and an unfair offer, thus favoring models of fairness in which not only the outcome matters, but also how the outcome came about (Dufwenberg \& Kirchsteiger 2004; Falk \& Fischbacher 2006).

\footnotetext{
${ }^{5}$ In some remote small scale societies (e.g. among the Machiguenga, a small tribe in the Peruvian Amazon) such fairness norms seem to be absent (Henrich et al. 2001). Likewise, chimpanzees also don't reject low offers in the ultimatum game (Jensen et al. 2007).
} 
Evidence from surveys indicates that individuals feel strongly about the perceived fairness of wage changes. Kahneman et al (1986) show that individuals' fairness judgments about whether a pay cut was fair depend strongly on the reason why pay was cut: workers consider it highly unfair if a firm wants to cut pay simply because labor market conditions deteriorated, while cutting pay to save a firm from bankruptcy is more acceptable. Evidence from surveys with personnel managers and compensation officers shows that they also anticipate these motives in their employees (Agell \& Lundborg 1995; Agell \& Lundborg 2003; Bewley 1999). In the context of labor markets, an important and old question is whether individuals solely take the real buying power of their wages into account, or whether they also care about nominal wages. Dating back at least to Keynes (1936), some economists have assumed that individuals are not fully aware of changes in the price level, and thus also care about the nominal wage. Goette \& Huffman (2007) conduct a study with students about to enter the labor market. In their sample, fairness judgments are solely a function of the real wage, with one exception: Nominal wage cuts trigger very strong negative reactions. They argue that the salience of a nominal wage cut elicits strong negative emotions that sway the students' judgment. This evidence suggests that fairness judgments are primarily affected by real wages, except in the case of nominal wage cuts.

The reference dependence of fairness judgments and the associated framing effects have also been stressed by Kahneman et al. (1986), who show that wage cuts - which are perceived as losses - are viewed more unfairly than identical reductions in real pay that are perceived as an elimination of a gain. They gave, for example, respondents a scenario of a firm that paid a ten percent annual bonus over a longer period, and then abolished it. The vast majority of respondents considered this as fair, even though it effectively cut the workers' incomes by 10 percent. Other respondents were given a scenario where the workers' base wage was cut by 10 percent. In this case, the majority of the respondents stated that the action is unfair.

Taken together the experimental evidence overwhelmingly suggests that reference-dependent social preferences are an important component of the human motivational repertoire. This 
does, of course not mean that such preferences always play a role. In fact, the social preference models mentioned above make clear that in certain competitive environments such preferences may play little role (Bolton \& Ockenfels 2000; Falk \& Fischbacher 2006; Fehr \& Schmidt 1999). Therefore, it is important to describe the relevant labor market environment in some detail.

\section{The Economic Environment: Labor Markets and Employment Relationships}

Many microeconomic textbooks still treat labor markets as a special case of neoclassical trade theory. Instead of trading physical products, the employer and the worker simply exchange well defined units of labor at a price market competition determines. The literature on the theory of the firm has long recognized that this simple view is not accurate, as it neglects many important aspects of real life employment relationships (Coase 1937; Simon 1951; Williamson 1975). Most occupations involve multidimensional and complex tasks that are hard to describe in a perfectly fashioned complete contract. The problem is that when the parties conclude the contract, they cannot foresee all the relevant contingencies that may become important in the course of their relationship. As a consequence, the typical employment relationship is governed by an incomplete contract that does not perfectly specify important aspects of the collaboration between the employer and the worker. Contractual incompleteness makes it hard for third parties like a court to evaluate whether the parties have met their obligations, therefore severely limiting the judicial enforceability of the contract. As a result, the employer faces a fundamental problem: if duties and obligations are only vaguely specified, how can the employer motivate the worker to provide more than minimal effort?

\subsection{Explicit versus implicit incentives}

If the worker's output is easy to measure, pay for performance may be a simple solution to the motivation problem. If the worker's earnings depend on his output, it is in his interest to exert non-minimal effort, even though nobody can legally force him to do so (Grossman \& Hart 1983; Harris \& Raviv 1979; Ross 1973). However, agency theory also provides important 
arguments for why firms may want to refrain from explicit performance pay. One problem with explicit incentives is the so called "multi-tasking problem" (Baker 1992; Holmstrom \& Milgrom 1991). Output is complex in many jobs, and only some of its many dimensions are objectively measurable, while others are not. In these cases, the provision of explicit incentives may cause distorted outcomes because workers will allocate all their effort toward those activities the incentive scheme rewards. Incentive pay is thus not effective if workers should devote time and effort to activities which contribute to the non-measurable dimensions of output. There is laboratory (Fehr \& Schmidt 2004) and field evidence (Prendergast 1999) for the relevance of the multi-tasking problem. Another related problem is that performance pay may create severe intertemporal problems. The issue is that the employer will always be tempted to adjust the standard for a performance evaluation based on the worker's past performance. If the worker anticipates that there is a tendency for the standard to increase after a period of good performance, the incentives to provide high effort are diluted - a phenomenon that has been called "the ratchet effect" (Carmichael \& MacLeod 2000; Freixas et al 1985; Gibbons 1987; Kanemoto \& MacLeod 1992; Laffont \& Tirole 1988; Lazear 1986). In order to avoid the ratchet effect, the employer may want to commit to fixed piece rates. But even if such a commitment is credible, the limited ability to react to innovations and progress may reduce the attractiveness of explicit performance pay considerably for the employer. Survey evidence on the prevalence of different compensation forms indicates that there seem to be strong limits to the usage of explicit incentive contracts. Explicit performance pay is still the exception rather than the rule. The vast majority of workers is compensated with hourly wages or salaries and not governed by formal incentive contracts (MacLeod \& Parent 1999).

The fact the many firms seem to be constrained to pay flat wages obviously does not mean that they are unable to provide incentives to their workers. Even if the worker's compensation does not explicitly depend on performance, the employer may use the threat of dismissal in case of poor performance or the promise of promotion for extraordinary performance to motivate the worker. In order for these implicit incentives to be effective, it is essential that the worker judges remaining with his current employer to be more attractive than his next best 
alternative. In other words: the prospect of keeping his job (or getting promoted) must provide the worker with a non-competitive rent. The literature on conditional contract renewals in repeated interactions between employers and workers shows that such implicit incentives can endogenously enforce the provision of non-minimal effort under incomplete employment contracts (MacLeod \& Malcomson 1989; MacLeod \& Malcomson 1993; MacLeod \& Malcomson 1998; Shapiro \& Stiglitz 1984). The basic mechanism in all these models is that the employer provides incentives to perform by conditioning the renewal (or the terms) of the employment contract on the worker's past performance.

\subsection{The Role of Fairness Concerns under Incomplete Relational Contracting}

In the ultimatum game, concerns for fairness and reciprocity cause rejections of unfair offers and induce proposers to make fair offers. In the context of contractually incomplete employment relations such concerns are also likely to affect workers' effort choices. The reason is that the preference for fairness or reciprocity induces workers to choose a higher effort to raise the firm's payoff in response to wage increases (Akerlof 1982; Akerlof \& Yellen 1990; Benjamin 2005). However, as we discussed in section 2, there is considerable individual heterogeneity in the preference for fairness and reciprocity, and a significant share of subjects often behaves in a completely selfish manner. As a consequence, the one-shot effects of fairness may not be strong enough to make the provision of non-competitive wage premia profitable.

The prevalence of repeated interactions in relational labor contracts, however, greatly amplifies the possibilities for fairness concerns to play a decisive role. This holds even if employers and employees know that they will only interact for a limited number of periods, i.e., even in cases of very limited time horizons. In a finitely repeated context, the presence of even a small fraction of fair-minded workers may also motivate purely selfish workers to exert effort in response to receiving a wage rent (Brown et al 2004; 2008; Kreps et al 1982). The intuition is that selfish workers have an incentive to exert effort in order to maintain a good reputation and make the employer believe that they are (at least potentially) fair-minded. 
Such a reputation is valuable for selfish workers because finite repetition implies that the employer only pays non-competitive rents to workers who have not yet been identified as selfish. The firm anticipates that a selfish worker will always shirk in the final period of the interaction, which unravels all incentives to pay a rent in any period if a worker is known to be selfish. Fair-minded workers, in contrast, exert effort whenever they are paid a fair wage rent. Thus, if the belief about an individual worker's fair-mindedness is high enough, the employer will be willing to pay a high wage even in the last period. Note that the employer's willingness to pay a rent to fair workers disciplines the selfish worker because if the worker shirks he will be identified as a selfish type which, in turn, implies that he will not be paid a rent in the future.

It is important to stress that the existence of reputation equilibria in which all workers selfish and fair-minded - put forward high effort despite the absence of explicit incentives does not require a large share of fair-minded workers. It is perfectly possible for the fraction of fair-minded individuals to be so small that firms would optimally refrain from paying noncompetitive wage premia in one-shot interactions, while finding it profitable to pay such premia in the reputation equilibria of finitely repeated interactions.

It is sometimes argued that the assumption of the existence of fair-minded individuals in infinitely repeated games is not needed to prove the existence of equilibria with noncompetitive wage rents. ${ }^{6}$ Even if all people are selfish, non-competitive rents can be equilibrium phenomena, provided that interactions are infinitely repeated. While, this argument is true, it is not important for our purposes because the existence of fair-minded subjects is an empirical fact. Physicists also don’t argue that we can explain sunset and sundown by assuming that the sun orbits around the earth although this incorrect assumption can provide a superficially plausible explanation for these phenomena. In addition, as the next section shows, it is an empirical fact that selfish subjects mimic fair-minded behaviors in repeated interactions (see e.g. Fehr, Brown, and Zehnder 2009). Moreover, because there are

\footnotetext{
${ }^{6}$ The papers by Shapiro and Stiglizt $(1984)$ and Malcomson and MacLeod $(1989,1998)$ demonstrate the existence of such equilibria.
} 
fair subjects, the range of parameter values (e.g. discount factors) for which equilibria with non-competitive wage premia exist is greatly expanded. Finally, fairness concerns may play a role as an equilibrium selection device, as argued in MacLeod and Malcomson (1998) ${ }^{7}$ and judgments regarding the fairness of performance evaluations are important whenever performance cannot be objectively assessed (MacLeod 2003).

\section{Motivating Workers: Evidence on the Role of Fairness and Reputation}

In this section, we discuss the empirical role of fairness preferences for the motivation problem in contractually incomplete employment relationships. The cleanest evidence comes from laboratory experiments which implement the essential strategic features of the interaction between employer and worker. In interpreting the lab studies, there is a natural concern that the effects of fairness identified in the lab may not carry over to the labor markets outside the laboratory (Levitt \& List 2007). However, we can allay these doubts by illustrating that the laboratory results are consistent with the findings in field experiments which implement explicit wage manipulations in real-life work environments and other field evidence from instances when firms changed the conditions in employment relationships.

In the first part of the section, we review evidence on the impact of fairness in one-shot encounters between employers and workers. Since reputational considerations cannot play a role in these situations, this evidence reveals the extent to which fairness motives alone help to overcome incentive problems in employment relationships. While there is clear-cut evidence that a non-negligible number of individuals are fair-minded and respond to higher wages by exerting more effort, the evidence also shows that many people are quite selfish and fairness concerns alone may not be sufficient to overcome the motivation problem in

\footnotetext{
${ }^{7}$ Another argument that is sometimes put forward is that because many interactions in real life are repeated, people apply rules of thumb or habits of fair behavior in one-shot interactions. However, while it is true that many interactions are repeated, people in modern societies also face many one-time encounters. Moreover, for our account of the labor market the origin of fairness preferences is not important. Whether many of us behave fairly because our parents imputed these values into our brains, or whether genes favor fair behaviors, is not important for our purposes. We have to take such behaviors seriously regardless of their evolutionary or educational origins.
} 
incomplete employment contracts. In fact, if fairness concerns are the only force that drives effort above non-minimal levels, there are in general large unexploited efficiency gains.

In the second part, we discuss how labor market outcomes change if employer and worker have the option of interacting repeatedly with each other. We show that reputational incentives in endogenously formed long-term relationships greatly magnify the impact of fairness on performance. In fact, the data indicate that the interaction between fairness and reputation effects can be sufficiently strong to sustain high levels of efficiency, even when the impact of fairness preferences alone is very weak.

\subsection{Fairness in Spot Interactions}

A well suited game for studying the impact of wage rents on effort is the so-called giftexchange game, which was introduced by Fehr et al (1993). The gift-exchange game is a twoplayer game that captures the basic strategic features of an incomplete employment contract. The structure of the game is as follows: the employer offers a wage to the worker and requests a certain level of effort. While the wage payment is binding, the requested effort level is not enforceable. The worker can either accept or reject the employer's offer. In case of acceptance, the worker can choose his actual effort level. The worker can choose any effort level and is not restricted by the employer's request. If the worker rejects the offer, he receives an unemployment benefit. The employer's profit is equal to the returns generated by the worker's effort minus the wage payment. The worker's payoff, in turn, is calculated as the wage minus the cost of effort. The parameters are usually chosen in such a way that the efficient outcome is achieved when the worker chooses the maximal effort level.

Since providing effort is costly, the self-interest model predicts that the worker always provides the smallest possible effort. However, if fairness considerations matter and workers are willing to reciprocate a generous wage with higher effort, it may be profitable for employers to offer wages that exceed the worker's outside-option. 
A typical example for a one-shot gift exchange experiment is the baseline treatment in Brown, Falk and Fehr (2004). Each employer can at most hire one worker in each period and each worker can have in maximum one job. The matching of workers and firms occurs in a simple labor market with an excess supply of workers. A match occurs when a worker accepts a firm's offer. Although the market runs for several periods, reputation formation cannot play a role, because employers cannot distinguish workers from each other when they make wage offers. The results confirm that higher wage offers by firms, on average, induce workers to provide more effort. However, while effort is significantly higher than the minimal effort predicted by self-interest, it is also far below the efficient level ${ }^{8}$. The reason for the limited impact of fairness on performance is found in the huge inter-individual differences across subjects. Although there are the fair-minded workers, there is also a substantial share of workers who make mostly selfish choices. The relationship between wages and effort is steep enough to render wage offers above the worker's outside option profitable, but the presence of selfish agents restrains many principals from offering wage rents which would be high enough to induce efficient effort levels from fair-minded workers.

The finding that the impact of fairness alone on market performance is positive but small is very robust and has also been confirmed in a number of other laboratory studies using students as participants (Charness 2004; Charness et al 2004; Falk \& Gaechter 2002; Fehr et al 1993; Hannan et al 2002). All report evidence from one-shot gift-exchange experiments and find results very similar to those reported above: wages and effort are always positively correlated, but the realized effort level is far from efficient. Fehr et al (1998) and List (2006) replicate the gift-exchange findings in laboratory experiments with non-student subject pools (soldiers and sportscard enthusiasts, respectively) and find that the realized effort levels are similar to those reported in the previous literature.

In order to assess the external validity of the laboratory findings on the impact of fairness on performance in employment relationships, several recent studies report evidence from field

\footnotetext{
${ }^{8}$ Workers can choose effort levels between 1 and 10 where 10 is the efficient effort level. The realized average effort level is about 3.
} 
experiments on gift-exchange. These studies aim to test the proposition that higher wages are perceived as fairer and consequently elicit higher effort in real-life work environments. Gneezy \& List (2006) hire workers to enter books into a library information system. The workers are made aware that this is a one-time employment with no scope for further work later on. The workers are either paid a low wage (\$12) or a high wage (\$20) per hour, with no particular reason given for the pay. Overall, output is approximately 10 percent higher when workers are paid the high wage, but because of large variations across individual output levels and a small sample size (about 10 participants per condition), this difference is not statistically significant. $^{9}$

Al-Ubaydli et al (2006) conduct a similar study with larger sample sizes (about 30 participants per condition). They use a temporary work agency to recruit workers for stuffing envelopes. Their rich setup consists of two treatments which allow a clean comparison regarding fairness. All workers in these two conditions were told upon hiring that their hourly wage will be somewhere between $\$ 8$ and $\$ 16$. Subsequently, the workers in one condition were paid \$8 per hour, while those in the other condition were paid \$16 per hour. The number of finished envelopes is about 22 percent lower when workers are paid \$8 compared to when they are paid $\$ 16$. This difference is highly significant, but it is unclear whether the effect was mainly caused by workers feeling that they were treated unfairly after they received $\$ 8$, or whether the highly paid workers put in extra effort. In general, studies that provide a salient manipulation of unfairness have provided the clearest results. Kube et al (2006) hired students to enter data. All workers were told that they would presumably earn 15 Euros per hour. Later on, some workers are indeed paid 15 Euros, while two other groups are paid 10 Euros or 20 Euros, respectively. Workers who were surprised with a high wage worked about 10 percent more than workers who received the announced wage but again, perhaps because of the small sample, the effect is not significant and it is therefore not possible to make strong statements.

\footnotetext{
${ }^{9}$ The positive impact of wage increases fades over time in the studies reported in Gneezy and List (2006). However, other studies (mentioned below) did not replicate this finding. It is also surprising that Gneezy and List did not find a learning effect in their task (average output is constant or even decreasing over time), while other studies implementing the same task (Kube et al. 2006 and 2008) find a steep rise in output over time in all treatment conditions. Likewise, the experiment of Cohn et al (2007) - which lasted for several weeks and is described in more detail below - did not replicate the finding of Gneezy and List.
} 
However, when workers received the low wage of 10 Euros, the reduction in effort relative to the baseline of 15 Euros is so large (27 percent) that it is significant despite the small sample. These results confirm that another well established result from the laboratory is also present in the field: while the positive effects of fair treatment on behavior are usually small, the negative impact of unfair behavior is often rather large (Offerman 2002).

The studies discussed so far did not examine the specific mechanisms underlying the response (or absence of a response) to wages. One possibility would be to vary the nature of the treatment, e.g., if the principal signals thoughtfulness and caring about one's workers. Kube et al. (2008) hire students for a data entry task and announce earnings of $€ 36$ for the three-hour work episode. They compare their baseline treatment where they pay the $€ 36$ to two different gift treatments. In the monetary gift treatment, the wage is raised to $€ 43$, i.e., a wage increase of $€ 7$, when the subjects show up for work. In the material gift treatment, the workers receive a gift in the form of a Nalgene bottle worth 7 Euros. The wage increase of 7 Euros induces the subjects to enter approximately 6 percent more data than in the baseline treatment. As usual, the effect is not large enough to be significant, given the small samples. ${ }^{10}$ However, when the subjects receive the Nalgene bottle, there is a highly significant increase of about 30 percent in entered data. This effect also prevails in a treatment in which the price of the Nalgene bottle was saliently visible for the subjects. Moreover, in a subsequent binary choice experiment, the authors gave (other) subjects the choice between the bottle and $€ \$ 7$; the vast majority of the subjects preferred the money over the bottle. This suggests that the positive effect of the material gift on effort is not primarily due to the economic value of the gift but that the signaling value of the gift is also important. A plausible interpretation is that the workers appreciate it if their employer cares for their welfare and this appreciation may lead to higher effort levels. The results of Kube et al (2008) provide a rationale for why job rents may contain non-monetary components.

\footnotetext{
${ }^{10}$ Notice, however, that the effect of raising the wage above the baseline is positive in every study we have discussed so far. Taking all five studies into account, the probability of this occurring is $\mathrm{p}=0.5^{5}<0.05$ under the null hypothesis of no effect. Thus, the overall evidence rejects the hypothesis that wage increases do not affect effort.
} 
A second approach towards a better understanding of the mechanisms behind gift exchanges is to collect information from outside the experiment to examine how the response to a wage increase is modulated. Cohn et al (2007) implement a wage increase during a newspaper promotion that took place when a publisher launched a new newspaper. It was clear from the outset that the promotion would last at most a few weeks. Therefore, the workers who were hired to distribute the newspaper at train stations and other public places did not have the prospect of long-term employment. The workers were given a CHF 5 increase over their regular hourly pay of CHF 22 and asked to approach the passers-by as actively as possible in return for the higher pay. Ten weeks after the experimental wage increase, Cohn et al. (2007) conducted a follow-up survey among the workers in which they measured the wage the workers thought would be appropriate for their work. In addition, they conducted a laboratory experiment in order to elicit workers’ propensity for reciprocal fairness. They find that only those workers who felt treated unfairly at the base wage and who displayed positive reciprocity in the laboratory experiment showed a significantly positive effort response to the wage increase. Individuals who already felt treated fairly at CHF 22 did not respond to the wage increase. Likewise, those who behaved selfishly in the lab experiment also did not respond to the wage increase - regardless of whether they felt underpaid or not. This finding shows that lab experiments can be very useful for understanding what is going on in field experiments. In addition, the finding is in line with the fair wage-effort hypothesis (Akerlof \& Yellen 1990) which predicts no effort response for fairly paid or overpaid employees, while underpaid workers are predicted to respond to wage variations. These results also show the importance of explicit controls for workers' fairness preferences and fairness perceptions; and they indicate the relevance of individual heterogeneity and the current base wage for an aggregate gift exchange effects: If workers already receive a high current wage, the percentage of individuals likely to judge this wage as unfair is relatively low; only few individuals will therefore respond to a wage increase with higher effort, and the average effect is likely to be small. In contrast, if the current base wage is relatively low, many individuals will feel underpaid and finding a positive average gift exchange effect is thus more likely. ${ }^{11}$

${ }^{11}$ This argument may be relevant for the interpretation of Gneezy and List (2006). According to personal communication from Uri Gneezy, the going market wage for the library task in this study was $\$ 7$ per hour while 
To summarize, field experiments confirm the lab finding that paying higher wages leads to an increase in effort, although - depending on the circumstances - the effects may be small. The wage elasticity of workers outputs ranges from roughly 0.15 in Gneezy and List (2006) to 0.30 in Kube et al. (2006) and Kube et al. (2008), and to 0.44 in Al Ubaydly (2006). In the case of unambiguous wage cuts, the elasticity is 0.82 in Kube et al. (2006), and it rises to roughly 1.45 if a material gift is provided (Kube et al 2008). This evidence is consistent with the idea that effort is more responsive to wage cuts than to wage increases and that the psychological properties of the gift (money versus a non-monetary gift) matter. One study (Cohn et al 2007) also supports the notion that the fairness perceptions mediate effort responses to wage increases, thus providing more direct support for the gift exchange hypothesis (Akerlof and Yellen 1990). These results also contradict the proposition that laboratory findings rarely carry over to field setting because - so the claim - the field is fundamentally different (List and Levitt 2007). Like in the laboratory, the field experiments show that the impact of fairness in one-shot interactions is likely to be small. Likewise, lab and field experiments suggest that the response to unfairness (i.e., a wage cut) is stronger than the response to kind behavior (i.e., a same-sized wage increase). Finally, as Cohn et al. (2007) show, there is not only consistency between lab responses and field responses to kind acts but the lab experiment also helps us to better understand the effort responses observed in the field.

\subsection{Fairness in ongoing Relations}

In the studies described above, the authors deliberately implemented conditions that rule out incentives arising from long-term labor relations because they were interested in the forces governing work effort when reputational incentives are absent. However, employment relationships are seldom spot market transactions where trading partners interact only once. Therefore, we summarize in the following labor market studies from settings that are

the base wage in the neutral treatment was $\$ 12$ per hour. Thus, by paying such a high wage in the neutral treatment it seems likely that workers perceived this wage as already quite fair. Therefore, a further wage increase to $\$ 20$, even though it is considerable, should have little effect. 
characterized by the possibility of forming long-term relations. With regard to the experimental evidence, we will focus on papers that implemented opportunities for repeated interactions in a setting with a publicly known finite number of periods. This design feature implies that if the selfishness of all participants is common knowledge, the only equilibrium in the finitely repeated game is identical to the equilibrium in the one-shot game. We can thus conclude that deviations in behavior in the repeated interaction treatments with regard to the one-shot treatments arise from the interactions between fairness and reputation effects.

An early paper that investigates the effect of repeated interactions in a gift-exchange setup is Falk and Gächter (2002). They set up a laboratory experiment with two treatments. In the baseline treatment, each participant plays a sequence of ten one-shot gift-exchange games with 10 different partners. In the main treatment, subjects play the same gift-exchange game ten times with the same partner. Each pair of subjects in the second treatment thus has a common history, and both participants can always condition their actions on their past experience with their partner. The results of this study reveal that reputational incentives in finitely repeated interactions amplify the positive impact of fairness on performance. The wage-effort relationship is steeper, and average efforts are significantly higher in the treatment with repeated interactions than in the one-shot treatment. The effort level, which can be chosen between 0.1 and 1 , stabilizes at about 0.55 in the repeated treatment after the first few periods, while the effort level in the one-shot treatment evens out around 0.35. The reason for this difference is that in the repeated condition many subjects in the role of an employer offer high wages only if their worker always provided high effort in the past. As a consequence, selfish workers have a strong incentive to hide their type and imitate the behavior of fair workers. By providing high effort in response to high wage offers, selfish workers can build up a reputation of being fair. Due to the conditional offering strategy of employers, such a reputation is of value, as it gives the workers access to attractive future offers from which they would be excluded if their true type were revealed. In the final period, when reputational concerns no longer matter, the effort level in the treatment with repeated interactions drops approximately to the level of the one-shot treatment. This end-game effect 
shows that fairness concerns genuinely motivate roughly the same fraction of subjects in both treatments. However, the long-term nature of the repeated treatment disciplines many selfish individuals who would - in the absence of repeated interaction - play uncooperatively.

Brown et al. (2004) allow long-term employment relationships to arise endogenously in a market environment with an excess supply of labor. In this experiment, which lasts for 15 periods, employers may address their wage offers to specific workers. They can therefore endogenously build up a long-term relationship with a worker by renewing offers to the same worker in consecutive periods. The comparison of this treatment to a treatment in which longterm relations are excluded provides the basis for measuring the impact of reputation incentives and the interaction of such incentives with fairness concerns. The possibility of contract renewals has strong positive effects on performance: It increases average effort from 3.3 in the treatment with one-shot interactions to 6.9 in the "relations treatment". In fact, the modal effort choice is at the minimum in the one-shot condition, while the maximum effort is the modal choice in the relations treatment. There is an end-game effect as in the Falk and Gächter (2002) paper because the selfish players do no longer put forward non-minimal effort levels in the final period.

One interesting aspect in these papers is that the selfish players do not merely raise their effort levels when they can acquire a good reputation, but they literally mimic the effort patterns of the fair-minded players in the non-final periods. This means that they provide low effort in response to low wages and high effort in response to high wages, thus contributing to the steepness of the wage effort relationship. As a consequence, employers face a strong incentive to pay non-competitive job rents because this enables them to elicit high effort from both fair and from selfish workers.

In the meantime, a series of additional papers has confirmed the robustness of the finding that reputation formation in relationships that evolved endogenously greatly fortifies the positive impact of fairness on performance. These papers provide evidence that reputation effects can 
be sufficiently strong to sustain very high levels of efficiency, even under rather adverse conditions. ${ }^{12}$ Fehr et al (2009)and Brown \& Zehnder (2007) show that reputation formation in long-term relations leads to stable trades, even when fairness alone cannot prevent a market collapse. Fehr \& Zehnder (2006) confirm this finding in a setup where asymmetric information implies that output is only an imprecise indicator for effort. Finally, Brown et al. (2008) illustrate the effectiveness of the interaction between reputational incentives and fairness in a market with excess demand for labor and no threat of unemployment.

Evidence from the field on the role of gift exchange in repeated interactions is provided by a recent study (Bellemare \& Shearer 2007) which reports observations from a field experiment in a tree-planting firm. Bellemare and Shearer implement a onetime wage gift and examine the workers' response. They show that effort increases significantly. The setup in this study is somewhat complex, as the tree planters are paid a piece rate and the income change induced by the wage gift may interact with these explicit incentives (see Goette et al (2004)) for a discussion of these motives). However, one may argue that it is even more remarkable to find a gift effect on effort in a piece rate environment where workers' marginal cost of effort provision is already presumably quite high. The study also provides evidence on the interaction between fairness and repeated game effects because they have workers in their sample who did not return to their employer during the next tree-planting season. They show that the effect of the wage gift on effort is significantly positive for both types of workers but for those who returned the next season the effect is stronger. This pattern confirms the complementarity between fairness effects and repeated game effects that is predicted by theory and observed in the laboratory.

Other evidence on gift exchange in repeated interactions is more indirect and circumstantial. In these cases, firms changed the employment conditions in ongoing employment relations in ways that plausibly led to a negative effect on workers' fairness perceptions. It is interesting to study these episodes, because they can be interpreted as a permanent change in the firm's

\footnotetext{
${ }^{12}$ For a much more detailed discussion of these papers see Fehr et al (2009).
} 
policy towards its workers. Krueger \& Mas (2004) examine the quality of Bridgestone/Firestone tires manufactured in different plants and years. The plant in Decatur, IL, experienced serious labor strife after the company not only announced lower wages for new hires and unfavorable changes in the schedule for shift rotations, but also threatened to fire existing staff and hire replacement workers (and later did so.). The results show clearly that tires manufactured during the labor strife at Decartur were of significantly lower quality compared to the same type of tires manufactured at different plants in the same years.

In a similar vein, Mas (2008) presents evidence showing that a labor dispute at Caterpillar, a large manufacturing company producing construction equipment, tractors, and other vehicles, had a similarly negative impact on production quality. Negotiations between the union and management broke down after Caterpillar refused to accept a contract that the same union had closed with John Deere, a firm similar to Caterpillar. Relative to comparable Caterpillar equipment produced outside the U.S, the equipment produced in the U.S. during the labor strife shows a lower resale value. Since effort is an important determinant of quality in this business, this indicates that effort was lower during labor strife.

No studies exist that examine how the repeated nature of an employment relationship affects the effectiveness of gift exchange in labor markets. Maréchal \& Thöni (2007), however, conduct an experiment in a related field study that allows them to tap into a similar business context. They show that sales representatives who visit stores to sell pharmaceuticals can increase sales by giving the store manager a gift - consisting of 6 samples of a product - at the beginning of their visits. Giving a gift strongly increases sales during the representative's visit from approximately CHF 60 in the condition without gift to about CHF 270 in the gift condition. Interestingly, the effect is only present if the sales representative had already visited the store; gifts on first visits lead to no change in sales. This suggests that the gift taps into an ongoing relationship between the sales representative and the store manager where the effects of fairness are predicted to be largest. 
There is also evidence that employers' actions that are considered unfair trigger stronger responses than those that are considered fair. Mas (2006) examines the outcomes of finaloffer arbitration cases that involved police departments in New Jersey, in which the police officers' union and the city were unable to negotiate a new contract. In this case, it is rather clear which of the outcomes the workers find fairest, as they would not end up in final-offer arbitration if they did not disagree with the offer the employer made. The study documents a large and significant decline in many indicators of police performance (e.g., number of crimes cleared, probability of incarceration, etc.) if the arbitrator's decision favors the employers. This decline in effort is highly sensitive to the size of the loss relative to the expected outcome from final-offer arbitration. If the arbitrator rules in favor of the union, there is a small positive effect on performance, which is almost completely insensitive to the size of the gain.

Lee \& Rupp (2007) examine the impact of wage cuts for airline pilots on flight delays. Virtually all the pay cuts they examine were consensual, i.e., the pilot union agreed to take a cut, as many of the airlines were in, or on the verge of, bankruptcy. There is essentially no effect on delays when pay cuts are consensual. This is in line with the survey evidence in Bewley (1999), showing that workers are willing to accept pay cuts when they feel they are justified, e.g., by the looming bankruptcy of the employer. However, there is one pay cut in Lee and Rupp (2007) that was the result of arbitration, and opposed by the pilots - a 26\% pay cut at Alaska Airlines. This instance of a pay cut is thus comparable to Mas (2006), and the records show that it lead to a massive increase in flight delays at Alaska Airlines over the next several months, in line with the predictions from the fairness model.

To summarize, the field evidence on fairness manipulations in ongoing relationships shows that firms may incur extremely high costs if they treat workers in ways that are perceived as unfair. The evidence from Lee and Rupp (2007) also shows that, as indicated by survey evidence, that no adverse consequences follow from pay cuts that employees do not perceive as unfair (Bewley, 1999). Less is known, however, about the impact of treating workers in a way that is clearly perceived to be fair. While the results in Maréchal and Thöni (2007) are 
suggestive of positive effects from fair treatment, this remains to be documented in a labor market setting. In particular, long-term studies with explicit randomization or credible exogenous changes in compensation policies, such as adoption of a set of policies when a firm is bought by another firm, are needed.

\subsection{Internal Labor Markets}

In a pioneering book, Doeringer \& Piore (1971) assert that there is a sharp distinction between internal and external labor market arrangements. In particular, workers seem insulated from outside labor market conditions once they are employed in firms. They argue that these arrangements are difficult to explain from the viewpoint of a neoclassical model: "[W]e doubt that any of the major strands of conventional research will prove capable of assimilating the internal labor market into conventional theory in a useful and meaningful way." As we argue below, fairness preferences have interesting new implications for how firms set wages over time, giving rise to two of the most important features of internal labor markets.

The evidence on fairness perceptions suggests a shift in workers' perceived entitlement as they enter a firm (Kahneman et al 1986). When forming judgments about fairness, new workers compare the firm's offer to what they could otherwise earn in the labor market, evidence, while the evidence suggests that incumbent workers compare a proposed change in the employment relationship to the status quo. ${ }^{13} \mathrm{~A}$ second important regularity is that loss aversion appears to have a strong effect on fairness judgments. For example, a small decrease in the wage does much more damage to fairness judgments than a small increase in the wage does to boost fairness perceptions (Kahneman et al 1986). It is not clear, a priori, whether loss aversion in fairness judgments applies to the nominal or the real wage. The survey scenarios in Kahneman et al. (1986) hold the real wage cut constant, showing that over and above the loss in the real wage, individuals consider nominal wage cuts particularly unfair. Shafir et al (1997) also show that nominal wage cuts are genuinely perceived as more unfair and (Fehr \&

\footnotetext{
${ }^{13}$ A similar effect can be observed in the fairness judgments of price changes. For example, Bolton et al. (2003) find that, in repeated transactions, the price that a firm charged last was the relevant reference price, much more so than the price the competitors were offering.
} 
Tyran 2008; Fehr \& Tyran 2001) document that money illusion prevents a quick fall in prices after a negative monetary shock in an experimental price setting game. As discussed earlier, Goette and Huffman (2007) present evidence that the salience of a nominal wage cut forms the fairness judgment. They show that if nominal wages are not cut, individuals care strongly about real wage changes.

These features give rise to three specific predictions in the theoretical framework we discussed earlier. ${ }^{14}$ The first prediction the model makes is that entry-level wages and the wages of incumbent workers respond differently to changes in labor market conditions. Entrylevel wages should strongly depend on labor market conditions. If the labor market is tight, workers can find alternative employment at relatively high wages. Thus, a high wage is needed to elicit high effort. When unemployment is high, workers' outside offers will be worse, and they will be willing to exert effort for a lower wage. As a consequence, the firm's optimal entry-level wage is lower when the labor market is slack. For incumbent workers, however, the reference outcome is the contract that was in place the last period, not the worker's outside options. This in itself makes the incumbent workers' wages relatively independent of labor market conditions. The model also predicts cohort effects in wages: because last year's contract becomes the reference outcome for this year, keeping the same contract is viewed as fair. Thus, if a worker started out with a high entry-level wage, this wage will become the reference wage for the next period, influencing future wage outcomes. The third prediction is related to loss aversion: if workers' fairness judgments are more strongly affected when their situation worsens, then firms should be reluctant to cut wages. The fairness model is silent as to whether real or nominal wages are the relevant measuring stick for fairness judgments. However the evidence in Kahneman et al. (1986) and Goette and Huffman (2007) suggests that nominal wage cuts in particular are considered unfair.

\footnotetext{
${ }^{14}$ This section draws heavily on Benjamin (2005), in which proofs of all the statements can be found. See also Cabrales et al. (2008) for a theory of how social preferences affect labor markets. Their paper focuses on how concerns for fairness can provide incentives to segregate workers.
} 
The evidence is generally supportive of these predictions. Several studies document that job changers' wages are more cyclical than those of job stayers. Recent studies include (Devereux 2001; Devereux \& Hart 2006; Haefke et al 2006; Solon et al 1994). In all studies, wages of individuals entering firms are far more sensitive to business cycle variations. It should be noted that the fairness model does not predict that the incumbents' wages will never change. In particular, if the firm's profit rises, so should the incumbents' wages. Since the studies do not attempt to disentangle shocks that affect firms' profits (for example, productivity shocks) from other shocks (those that only change labor supply), there is no detailed test of this prediction. The study closest to testing this prediction is (Beaudry \& DiNardo 1991), who find that current labor market conditions have almost no effect on current wages, but initial labor market conditions are a significant determinant of entry level wages. Support also comes from several case studies of personnel files of firms (Baker et al 1994; Eberth 2003; Treble et al 2001). Compared to data from labor force surveys, such studies, while less representative, show a much clearer picture of how wages change over the course of a career. The evidence of cohort effects is also cleanest in these studies: the picture that emerges shows that entrylevel wages vary widely from year to year. Each cohort then gradually increases from the entry-level wage, thus preserving the initial differences in wages. (Oreopoulos et al 2006) use data on Canadian college graduates to examine the long-run effects of unemployment at the time of graduation on wages. They find very strong and long-lasting effects of the labor market conditions upon graduation on later economic outcomes. If graduating in a boom year (with an unemployment rate five percentage points lower), initial earnings are about 9 percent higher. After five years, long after the economy has slowed down again, earnings are still 4 percentage points higher and the effect only fades after ten years. ${ }^{15}$ One reason why these effects are so long lasting is that initial business cycle conditions change the job-mobility pattern permanently, as one would expect when these initial conditions permanently affect the firm's compensation policy.

\footnotetext{
${ }^{15}$ One might argue that the timing of graduation is endogenous to the business cycle. However, the results are robust to using the unemployment rate four years after enrollment as an instrument.
} 
There is also strong evidence that employers shy away from wage cuts, and freeze their employees' wages rather than making small wage cuts. There are two noteworthy features in the distribution of nominal wage changes. First, there is a clear drop in the density just below zero. A large fraction of individuals receive a nominal wage change of zero, but almost nobody receives small wage cuts. Second, small wage increases are frequent. Hence, there is a clear asymmetry in the distribution of wage changes: wage cuts occur less often than expected, as the model predicts. Virtually any study that examines the distribution of wage changes finds this pattern (see e.g. (Altonji \& Devereux 2000; Fehr \& Goette 2005; Wilson 1999)).

There are significant measurement problems when moving to more conventional data sets like the PSID or other labor market surveys; in particular, wages are typically reported with error (Bound et al 1994). This problem is accentuated when looking at wage changes, and may wrongly lead researchers to conclude that there is a substantial amount of wage flexibility. Indeed, studies that do not control for measurement error find a significant number of wage cuts, though these studies still find a strong asymmetry in the distribution of wage changes (Card \& Hyslop 1996; Dickens et al 2007; Kahn 1997; McLaughlin 1994). Several methods have been proposed for correcting for this problem: some rely on parametric modeling of measurement error (Altonji \& Devereux 2000; Fehr \& Goette 2005), while others are entirely non-parametric (Dickens \& Goette 2006; Gottschalk 2005). It turns out that the specific form of the correction has very little impact. All studies find, however, that correcting for measurement error is important: once these estimators are applied, the evidence obtained from the labor force surveys essentially looks like that from personnel files: there are only very few wage cuts.

Nominal wage rigidity or cohort effects could also be caused by forces other than a combination of fairness preferences and money illusion (Malcomson 1999; Malcomson 1997). Suppose, for example, that workers are risk averse, firms are risk neutral and working hours are fixed. Then there is an incentive for the firm to insure its workers against 
fluctuations in real wages. The real wage is then just given by the current labor market conditions and the optimal insurance condition; thus subsequent labor market events do not affect the real wage. This naturally leads to cohort effects in wages, as the starting wages will differ by year. Yet, these models have difficulties in explaining nominal wage rigidity because they predict that real, not nominal, wages should be insured. Other models (Malcomson 1999, 1997) show that contracts with a fixed wage can induce efficient levels of relationshipspecific investments. These models have the property that incumbents' wages only respond to exogenous conditions if the outside option becomes binding. Thus as long as the real wage is strictly within the boundaries of the real outside option, the nominal wage will not be adjusted to changes in real outside options. They are adjusted only when one of the outside options becomes binding. With positive inflation, this automatically implies that wage cuts will tend to be rare. However, the model also predicts that during deflation, wage cuts would be frequent, and raises rare, with the asymmetry going the other way. There is no evidence that during the great depression in the U.S., for example, wage cuts became frequent (Akerlof et al 1996). Similarly, Imfeld (1991) reports virtually no wage cuts in five large Swiss firms during the period between 1879 and 1890 when prices in Switzerland declined by 20 percent.

At the more aggregate level, our framework may also help explain some of the business cycle facts that the standard model has difficulty accounting for. First, the model offers a new source of wage stickiness. For example, the model readily predicts that employment should be more volatile than wages. The reason is that raising employment in the face of a positive demand shock lowers average profit (because of diminishing returns to effort). This persuades the workers to work harder for a given wage, because the wage is now higher relative to the average profit the firm makes per worker. This increases the workers' effort, but does not require paying a much higher wage. Therefore, most of the firm's adjustment will come through changes in employment, making the wage relatively unresponsive to changes in demand on the product market (Danthine \& Kurmann 2004). On the other hand, the model also predicts a difference between demand shocks and productivity shocks for wage and employment reactions. In contrast to the demand shock discussed above, a positive 
productivity shock increases the firm's profit directly. The workers will thus lower their effort for a given wage. However, because the workers' effort now becomes more valuable to firms, this reinforces the incentives of the firm to raise wages (Benjamin 2005; Danthine \& Kurmann 2004).

\subsection{Fairness and the Economic Effects of Minimum Wage Legislations}

In this section, we illustrate that the psychological forces described in section 2 may be crucial for a better understanding of labor market policy. If people have reference-dependent fairness preferences, policy measures may not only function by affecting outcomes but also by shifting the relevant reference points. We use the case of the minimum wage legislation to illustrate the empirical relevance of this possibility. The minimum wage example is an especially important one because minimum wages are one of the most often-used instruments in labor market policy (see e.g. OECD (1998) for evidence that minimum wage legislation affects most labor markets in the developed world in one way or another).

Despite the remarkable attention that minimum wage laws have received, three empirical findings remain puzzling in light of the standard approach in labor economics. First, a number of papers show that minimum wages have so called spill-over effects, i.e., many firms increase wages by an amount exceeding that necessary to comply with the higher minimum wage (see, e.g., Card \& Krueger 1995; Dolado et al 1997; Katz \& Krueger 1992; Teulings et al 1998; Teulings 2003). Second, several studies report anomalously low utilization of subminimum wages in situations where firms could actually pay workers less than the minimum (Freeman et al 1981; Katz \& Krueger 1991; Katz \& Krueger 1992; Manning \& Dickens 2002). For example, Katz and Krueger (1991) find that the introduction of the opportunity to pay subminimum wages to youth did not caused a significant decline in teenage workers' wages. Third, there are several cases in which an increase in minimum wages led to zero or even positive employment effects (see, e.g. (Card 1992; Card \& Krueger 1994; Katz \& Krueger 1992; Machin \& Manning 1994; OECD 1998; Padilla et al 1996). This 
is surprising, because the conventional competitive theory predicts that increases in minimum wages should always reduce employment.

A recent experimental study (Falk et al 2006) suggests that the phenomena mentioned above may be better understood if the labor market is viewed from the behavioral perspective we describe in this paper. In addition to the possibility that workers may have referencedependent fairness preferences, their experiment is based on the idea that labor markets are likely to exhibit imperfectly competitive features. This view is based on a recent line of research in labor economics stipulating that imperfect competition is perhaps the rule rather than the exception in labor markets (Boal \& Ransom 1997; Manning 2003). The rationale behind this argument is that labor markets are typically characterized by important frictions (like moving costs, heterogeneous job preferences, or social ties) which prevent the elasticity of an individual firm's labor supply from being close to infinity, a view that also receives empirical support (Barth \& Dale-Olsen 1999; Boal \& Ransom 1997; Manning 2003). Therefore it seems reasonable to assume that firms have at least a certain degree of wage setting power.

Falk et al. (2006) thus implement a simple laboratory labor market in which workers' mobility restrictions in combination with heterogeneous fairness preferences give rise to upward sloping labor supply schedules at the firm level. They observe that the minimum wage strongly affects reservation wages, suggesting that it provides an anchor for judging the fairness of the actual wage paid. After the introduction of the minimum wage, subjects in the role of workers strongly increase their reservation wages. While almost all reservation wages were clearly below the level of the minimum wage before its introduction, a substantial share of reservation wages lie above that level after its introduction. The impact of the introduction of the minimum wage on reservation wages is in line with the evidence presented in section 2.2. The mini-ultimatum games of Falk et al. (2003) revealed that changes in the set of available but not chosen alternatives may have important consequences for the perceived fairness of a specific action. The introduction of a minimum wage eliminates a whole range of 
previously possible wage payments from the firms' strategy set. As a consequence, many subjects seem to perceive a wage payment at the level of the minimum wage, which would have been considered as fair and quite generous before the introduction, as unfairly low after the introduction.

The impact of the minimum wage on reservation wages has important implications for the wage-setting strategy of profit-maximizing employers: they are forced to pay wages above the minimum. Thus, the strong impact of the minimum wage on subjects' reservation wages provides a possible explanation for the spillover effect empirically observed in field studies. Furthermore, the pattern of reservation wages also shapes the employment effects of the minimum wage. Since firms face upward-sloping labor-supply schedules, a wage increase may lead to higher employment for a firm's given labor supply schedule. However, since the minimum wage raises reservation wages, the labor supply schedule individual firms face shifts to the left. Accordingly, a potentially positive employment effect of the minimum wage introduction due to imperfect competition is dampened or may be even reversed because of the leftward shift in the labor supply schedule. Whether the introduction of the minimum wage ultimately leads to an increase or a reduction in employment depends on the parameters which shape the relative size of the two counteracting effects. The minimum wage has a positive net effect on employment under the conditions chosen in Falk et al. (2006). However, the effect is much smaller than it would have been, had subjects' reservation wages remained stable. $^{16}$

In contrast to the experimental settings discussed in the previous section, Falk et al. (2006) implemented a labor market with complete employment contracts. However, gift-exchange experiments by (Brandts \& Charness 2004; Kagel \& Owens 2006) show that the impact of minimum wages on labor supply also prevails if the labor market suffers from contractual incompleteness. Both papers show that the introduction of a minimum wage has two effects.

\footnotetext{
${ }^{16}$ Note that when individual firms face highly elastic labor supply schedules in a relatively competitive labor market, the impact of minimum wages on reservation wages exacerbates the employment reduction caused by the rise in minimum wages.
} 
On the one hand, the minimum wage increases average wages, which motivates fair-minded subjects to exert more effort. On the other hand, however, the minimum wage also changes the fair-minded subjects' willingness to provide effort at a given wage level. It seems that a law in place forcing employers to pay at least a certain minimum makes subjects perceive the same wage, once considered fair, to be less fair. As a consequence, the net effect of the minimum wage on effort is ambiguous and depends on the relative size of the two counteracting effects.

Falk et al. (2006) also find that the economic consequences of a removal of the minimum wage are very asymmetric relative to the effects of the introduction. While subjects' reservation wages decrease somewhat after the removal of the minimum wage, they still substantially exceed those before its introduction. It seems that the minimum wage leads to a kind of ratchet effect in subjects' perceptions of what constitutes a fair wage. Subjects who are used to receiving high wages seem to feel morally entitled to receive them even after the abolishment of the minimum wage legislation. The forces behind the stickiness of reservation wages, which are similar to the forces discussed in the context of downward rigidity of wages, also induce an asymmetry in the response of actual wages: the absolute change in wages after the introduction of the minimum wage is much larger than after its elimination, implying that minimum wage laws carry important hysteresis effects. Actual wages after the elimination of a minimum wage increase will tend to be higher than before the introduction of a minimum wage increase. The asymmetric effect of the minimum wage on reservation wages may explain why firms may find the utilization of subminimum wage opportunities unprofitable, because these opportunities were typically introduced after a previous increase in the minimum wage.

Of course, the laboratory experiment described above represents only the first step in a long lasting research endeavor. One experiment alone will never be conclusive - be it a lab or a field experiment. However, the results suggest interesting hypotheses and a high payoff for efforts directed at the collection of hitherto unavailable data, such as reservations wages. 
Moreover, as the literature on the gift exchange shows, effects that have been found in the laboratory may generalize to field settings outside the laboratory, and much is at stake in the current case. If the asymmetric impact of minimum wage laws on reservation wages turns out to be a robust finding, it will have profound consequences. First, it questions the basic assumption that the minimum wage does not affect labor supply. Second, the upwards shift in the labor supply curve that increases in the minimum wage generate introduces a further employment limiting aspect of minimum wage increases. Third, the asymmetric impact on reservation wages and actual wages challenges the standard assumption in economics that the size of a comparative static result does not depend on the sign of the change in the independent variable. If economic policies generate entitlement effects that respond asymmetrically to the introduction and the removal of the policy, much of what is taught in economic textbooks needs to be rewritten because the introduction of a policy may have effects that prevail even after it has been abolished. ${ }^{17}$ In the labor market context, this means that reductions in minimum wages are likely to cause much smaller employment effects than one would expect from standard competitive or monopsonistic models.

\section{Conclusions}

Many employment relations are only incompletely regulated by explicit contracts, giving employees discretion over their effort choices. In addition, these relations are embedded in a context of repeated interactions between employers and employees. We also know from a large experimental literature - which provides evidence from many different countries, from studies involving high stakes, and from nationally representative experiments - that a substantial share of the people exhibits (reference-dependent) social preferences and concerns for fair outcomes. In this paper we combine these insights and argue that they can help us provide a better understanding of phenomena such as downwards nominal wage rigidity, the unresponsiveness of incumbents' wages to labor market conditions, cohort effects or non-

\footnotetext{
${ }^{17}$ Asymmetric responses to the introduction and elimination of policy measures are of course not restricted to minimum wage legislation. Card and Hyslop (2006) show, for example, that a dynamic earnings subsidy increased participation of welfare recipients in the labor market even after the subsidy expired.
} 
competitive wage premia. Such phenomena are hard to reconcile with the competitive model, but they follow in a relatively straightforward manner from a labor market account that acknowledges (i) the inherent incompleteness and relational nature of most employment contracts and (ii) the existence of reference-dependent fairness concerns that are shaped by nominal loss aversion. Direct evidence from laboratory and field experiments is supportive of our account which is also strengthened by the insight that even a small share of fair-minded workers can have a large impact on long-term employment relations because reputational concerns in repeated interactions greatly magnify the impact of fairness concerns.

The evidence we survey also has several implications for policy and raises new questions. First, downward nominal wage rigidity may create a permanent tradeoff between inflation and unemployment: In an economy with heterogeneous productivity changes the productivity of some jobs rises while some jobs become less productive. In the more productive jobs real wages will rise while in jobs with a productivity decrease real wages should fall. However, at low levels of inflation a real wage cut can only be achieved by cutting nominal wages. Thus, if downwards nominal wage rigidity prevails the aggregate real wage rises permanently because firms are reluctant to cut nominal wages. This reluctance acts like a productivity decrease in the economy and consequently depresses employment and output (Akerlof et al 1996). Second, the theory and evidence on internal labor markets more generally suggest that any temporary intervention can have effects that are much more long-lasting than the standard model suggests. The reason is that any temporary shock that affects entry-level wages matters for future wages because of their impact on the reference standards (see Fehr et al (2008) for a more detailed discussion).

Our results also raise several issues that future research needs to address. First, there is still little evidence on how fairness and relational contracting interact in the field. While it may not be feasible to finance a long-term experiment, it may be possible to tap into an existing environment and examine how a change in pay affects effort compared to a case in which there is essentially no future relationship. In this context it is also worthwhile to stress that 
from the perspective of our fairness account only those wage variations that are associated with perceived fairness variations will tend to change the workers' behavior (Cohn et al 2007). Thus, the psychological context in which wage variations take place needs to be taken into account to avoid the naive view that every wage increase leads to an effort increase. For example, if workers receive a surprise wage increase without any explanation, it is hard to see why they should view this as a fairness variation. This also means that researchers must not only collect data on wages and effort, but also important related information such as fairness judgments, workers' beliefs about the employers' intentions, or the rationale that employers give to the workers for why they increase wages, whether employers expect higher effort in return (and whether workers believe this), and the like.

Second, it is worth recalling that the theory and evidence we discussed here is related to issues of vertical fairness. This may suffice in some cases, i.e., when a firm only hires identical workers. As our discussion shows, vertical fairness concerns may lead firms to pay more generous wages, leading to particular wage dynamics. As such, this framework could also provide testable hypotheses which firms pay high wages, possibly explaining inter-industry wage differentials (Krueger \& Summers 1988). Our framework predicts that more profitable firms should pay more to all workers. ${ }^{18}$ However, issues of fairness between workers may become important in other cases (Livernash 1957). Several recent papers provide laboratory evidence on the role of horizontal social comparisons for workers' effort choices in a gift exchange environment (Charness \& Kuhn 2007; Clark et al 2006; Gächter \& Thöni 2005). Neuroimaging experiments also provide evidence for the importance of social comparisons (Fliessbach et al 2007) and there is also convincing field evidence that workers influence each other in choosing how hard to work (Mas \& Moretti 2008). A plausible interpretation of these results is based on horizontal fairness concerns, raising the possibility that such concerns are more generally important. They may constrain firms even more in their policies and may have even more sweeping implications than those discussed here. For instance, as pointed out in

\footnotetext{
${ }^{18}$ Our best interpretation of the long and ongoing controversy regarding the respective role of individual and firm heterogeneity contributing to the industry wage differentials is that a substantial part is due to genuine differences in firms’ wage policies (Abowd, Finer and Kramarz, 1999).
} 
recent work (Cabrales et al 2008), if workers strongly care about relative wages, this creates an incentive for firms to segregate workers of different skill levels, and also has implications for wage policies. No evidence exists on even the most basic implications from horizontal fairness concerns, and this is clearly an important area for future research. 
Abowd J, Finer H, Kramarz F. 1999. Individual and Firm Heterogeneity in Compensation: An Analysis of Matched Longitudinal

Employer and Employee Data for the State of Washington. In The Creation and Analysis of Employer-Employee Matched Data, ed. J Haltiwanger, J Lane, J Spletzer, K Troske, pp. 3-24: North Holland

Agell J, Lundborg P. 1995. Theories of Pay and Unemployment: Survey Evidence from Swedish Manufacturing Firms. Scandinavian Journal of Economics 97:295-307

Agell J, Lundborg P. 2003. Survey Evidence on Wage Rigidity and Unemployment. Scandinavian Journal of Economics 105:15-30

Akerlof GA. 1982. Labor Contracts as Partial Gift Exchange. The Quarterly Journal of Economics 97:543-69

Akerlof GA, Dickens WT, Perry GL. 1996. The Macroeconomics of Low Inflation. Brookings Papers on Economic Activity 1996:1-76

Akerlof GA, Yellen JL. 1990. The Fair Wage-Effort Hypothesis and Unemployment. The Quarterly Journal of Economics 105:255-83

Al-Ubaydli O, Andersen S, Gneezy U, List JA. 2006. For Love or Money? Testing NonPrecuniary and Pecuniary Incentive Schemes in a Field Experiment. Working paper: University of Chicago

Altonji JG, Devereux PJ. 2000. The Extent and Consequences of Downward Nominal Wage Rigidity. Research in Labor Economics 19:383-431

Baker G, Gibbs M, Holmstrom B. 1994. The Wage Policy of a Firm. The Quarterly Journal of Economics 109:921-55

Baker GP. 1992. Incentive Contracts and Performance Measurement. The Journal of Political Economy 100:598-614

Barth E, Dale-Olsen H. 1999. Monopsonistic Discrimination and the Gender-Wage Gap. NBER Working Paper No. 7197

Beaudry P, DiNardo J. 1991. The Effect of Implicit Contracts on the Movement of Wages over the Business Cycle: Evidence from Micro Data. Journal of Political Economy 99:665-88

Bellemare C, Kröger S. 2007. On Representative Social Capital. European Economic Review 51:181-202

Bellemare C, Kröger S, van Soest A. 2008. Measuring Inequity Aversion in a Heterogeneous Population using Experimental Decisions and Subjective Probabilities. Econometrica 76:815-39

Bellemare C, Shearer B. 2007. Gift Exchange within a Firm: Evidence from a Field Experiment. Working Paper

Benjamin D. 2005. A Theory of Fairness in the Labor Market. Harvard University, Cambridge

Berg J, Dickhaut JW, McCabe KA. 1995. Trust, Reciprocity, and Social History. Games and Economic Behavior 10 1:122-42

Bewley TE. 1999. Why Wages Don't Fall During a Recession. Cambridge: Harvard University Press

Bewley TF. 1995. A Depressed Labor Market as Explained by Participants. American Economic Review 85:250-54

Binmore K, Gale J, Samuelson L. 1995. Learning to be imperfect: The ultimatum game. Games and Economic Behavior 8:56-90

Boal WM, Ransom MR. 1997. Monopsony in the Labor Market. Journal of Economic Literature 35:86-112

Bolton GE, Ockenfels A. 2000. ERC: A Theory of Equity, Reciprocity, and Competition. American Economic Review 90:166-93 
Bound J, Brown C, Duncan GJ, Rodgers WL. 1994. Evidence on the Validity of CrossSectional and Longitudinal Labor Market Data. Journal of Labor Economics 12:34568

Brandts J, Charness G. 2004. Do Labour Market Conditions Affect Gift Exchange? Some Experimental Evidence. Economic Journal 114:684-708

Brown M, Falk A, Fehr E. 2004. Relational Contracts and the Nature of Market Interactions. Econometrica 72:747-80

Brown M, Falk A, Fehr E. 2008. Competition and Relational Contracts: The Role of Unemployment as a Disciplinary Device. IZA Discussion Paper 3345

Brown M, Zehnder C. 2007. Credit Reporting, Relationship Banking, and Loan Repayment. Journal of Money, Credit, and Banking 39:1883-918

Cabrales A, Calvo-Armengol A, Pavoni N. 2008. Social Preferences, Skill Segregation, and Wage Dynamics. Review of Economic Studies 75:65 - 98

Camerer C. 2003. Behavioral Game Theory: Princeton University Press

Cameron LA. 1999. Raising the Stakes in the Ultimatum Game: Experimental Evidence from Indonesia. Economic Inquiry 37:47-59

Card D. 1992. Do Minimum Wages Reduce Employment? A Case Study of California, 19871989. Industrial and Labor Relations Review 46:38-54

Card D, Hyslop D. 1996. Does Inflation "Grease the Wheels of the Labor Market"? NBER Working Papers, National Bureau of Economic Research

Card D, Hyslop DR. 2006. The Dynamic Effects of an Earnings Subsidy for Long-Term Welfare Recipients: Evidence from the SSP Applicant Experiment. National Bureau of Economic Research Working Paper 12774

Card D, Krueger A. 1994. Minimum Wages and Employment: A Case Study of the Fast-Food Industry in New Jersey and Pennsylvania. The American Economic Review 84:772-93

Card D, Krueger A. 1995. Myth and Measurement: The New Economics of the Minimum Wage: Princeton University Press

Carmichael HL, MacLeod WB. 2000. Worker Cooperation and the Ratchet Effect. Journal of Labor Economics 18:1-19

Charness G. 2004. Attribution and Reciprocity in an Experimental Labor Market. Journal of Labor Economics 22:665-88

Charness G, Frechette GR, Kagel JH. 2004. How Robust is Laboratory Gift Exchange? Experimental Economics 7:189-205

Charness G, Kuhn P. 2007. Does pay inequality affect worker effort? Experimental evidence. Journal of Labor Economics 25:693-723

Charness G, Rabin M. 2002. Understanding Social Preferences with Simple Tests. Quarterly Journal of Economics 117:817-69

Clark AE, Masclet D, Marie-Claire V. 2006. Effort and Comparison Income. IZA Discussion Paper 2169

Coase R. 1937. The Nature of the Firm. Economica 4:386-405

Cohn A, Fehr E, Goette L. 2007. Gift Exchange and Effort: Evidence from a Field Experiment. Working Paper: Institute for Empirical Research in Economics, University of Zurich

Danthine J-P, Kurmann A. 2004. Fiar Wages in a New Keynesian Model of the Business Cycle. Review of Economic Dynamics 7:107-42

De Quervain DJF, Fischbacher U, Treyer V, Schelthammer M, Schnyder U, et al. 2004. The neural basis of altruistic punishment. Science 305:1254-8

Devereux PJ. 2001. The Cyclicality of Real Wages within Employer-Employee Matches. . Industrial \& Labor Relations Review 54:835-50 
Devereux PJ, Hart RA. 2006. Real Wage Cyclicality of Job Stayers, Within-Company Job Movers, and Between-Company Job Movers. Industrial and Labor Relations Review 60:105-19

Dickens W, Goette L. 2006. Estimating Rigidity for the International Wage Flexibility Project. manuscript

Dickens WT, Goette L, Groshen EL, Holden S, Messina J, et al. 2007. How Wages Change: Micro Evidence from the International Wage Flexibility Project. The Journal of Economic Perspectives 21:195-214

Doeringer P, Piore MJ. 1971. Internal Labor Markets and Manpower Analysis. Armonk, New York: M. E. Sharpe, Inc

Dolado JJ, Felgueroso F, Jimeno JF. 1997. The Effects of Minimum Bargained Wages on Earnings: Evidence from Spain. European Economic Review 41:713-21

Dohmen T, Falk A., Huffman D., Sunde U. 2009. Homo Reciprocans - Survey Evidence on Behavioral Outcomes. Economic Journal.

Dufwenberg M, Kirchsteiger G. 2004. A theory of sequential reciprocity. Games and Economic Behavior 47:268-98

Eberth B. 2003. Cohort Wage Profiles in an Internal Labour Market. Royal Economic Society Annual Conference 2003, Royal Economic Society

Falk A, Fehr E, Fischbacher U. 2003. On the Nature of Fair Behavior. Economic Inquiry 41:20-6

Falk A, Fehr E, Zehnder C. 2006. Fairness Perceptions and Reservation Wages- The Behavioral Effects of Minimum Wage Laws. The Quarterly Journal of Economics 121:1347-81

Falk A, Fischbacher U. 2006. A theory of reciprocity. Games and Economic Behavior 54:293315

Falk A, Gaechter S. 2002. Reputation and Reciprocity - Consequences for the Labour Relation. Scandinavian Journal of Economics 104:1-26

Fehr E, Brown M, Zehnder C. 2009. On Reputation - A Microfoundation of Contract Enforcement and Price Rigidity. Economic Journal 119:in press

Fehr E, Fischbacher U, Rosenbladt Bv, Schupp J, Wagner G. 2003. A Nation-Wide Laboratory: Examining Trust and Trustworthiness by Integrating Behavioral Experiments into Representative Surveys. Schmollers Jahrbuch 122:519-42

Fehr E, Fischbacher U, Tougareva E. 2002. Do High Stakes and Competition Undermine Fairness? Evidence from Russia. Working Paper No 120, Institute for Empirical Research in Economics, University of Zurich

Fehr E, Gachter S. 2000. Fairness and Retaliation: The Economics of Reciprocity. The Journal of Economic Perspectives 14:159-81

Fehr E, Goette L. 2005. Robustness and real consequences of nominal wage rigidity. Journal of Monetary Economics 52:779-804

Fehr E, Goette L, Zehnder C. 2008. The Behavioral Economics of the Labor Market: Central Findings and their Policy Implications. Manuscript, Federal Reserve Bank of Boston

Fehr E, Kirchler E, Weichbold A, Gachter S. 1998. When Social Norms Overpower Competition: Gift Exchange in Experimental Labor Markets. Journal of Labor Economics 16:324-51

Fehr E, Kirchsteiger G, Riedl A. 1993. Does Fairness Prevent Market Clearing? An Experimental Investigation. The Quarterly Journal of Economics 108:437-60

Fehr E, Schmidt K. 2002. Theories of Fairness and Recriprocity- Evidence and Economic Applications. In Advances in Economics and Econometrics: Cambridge University Press

Fehr E, Schmidt KM. 1999. A Theory Of Fairness, Competition, and Cooperation. Quarterly Journal of Economics 114:817-68 
Fehr E, Schmidt KM. 2004. Fairness and incentives in a multi-task principal-agent model. Scandinavian Journal of Economics 106:453-74

Fehr E, Tyran J-R. 2008. Limited Rationality and Strategic Interaction. The Impact of the Strategic Environment on Nominal Inertia. Econometrica 76 (2):353-94

Fehr E, Tyran JR. 2001. Does money illusion matter? American Economic Review 91:1239-62

Fehr E, Zehnder C. 2006. Reputation and Credit Market Formation. FINRISK Working Paper, University of Zurich

Fliessbach K, Weber B, Trautner P, Dohmen T, Sunde U, Elger C, Falk A. 2007. Social Comparison affects reward related brain activity in the human ventral striatum. Science 318, 1305-1308.

Freeman R, Gray W, Ichniowski C. 1981. Low Cost Student Labor: The Use and Effects of the Subminimum Wage Provisions for Full-Time Students, Report for the Minimum Wage Study Commission, Washington, D.C.: GPO

Freixas X, Guesnerie R, Tirole J. 1985. Planning under Incomplete Information and the Ratchet Effect. Review of Economic Studies 52:173-91

Gächter S, Thöni C. 2005. Wage Comparisons and Performance: An Experimental Approach. Discussion Paper, University of St. Gallen

Gibbons R. 1987. Piece-Rate Incentive Schemes. Journal of Labor Economics 5:413-29

Gneezy U, List J. 2006. Putting Behavioral Economics to Work: Field Evidence of Gift Exchange. Econometrica 74:1365-84

Goette L, Huffman D. 2007. Do Emotions Lead to Better Labor Market Outcomes? In Do Emotions Lead to Better or Worse Decisions?: Russell Sage

Goette L, Huffman D, Fehr E. 2004. Loss Aversion and Labor Supply. Journal of the European Economic Association 2:216 - 28

Gottschalk P. 2005. Downward Nominal-Wage Flexibility: Real or Measurement Error? The Review of Economics and Statistics 87:556-68

Grossman S, Hart O. 1983. An Analysis of the Principal-Agent Problem. Econometrica 51:745

Güth W, Schmittberger R, Schwarze B. 1982. An experimental analysis of ultimatum bargaining. Journal of Economic Behavior \& Organization 3:367-88

Haefke C, Sonntag M, van Rens T. 2006. Wage Rigidity and Job Creation. 2006 Meeting Papers, Society for Economic Dynamics

Hannan RL, Kagel JH, Moser DV. 2002. Partial Gift Exchange in an Experimental Labor Market: Impact of Subject Population Differences, Productivity Differences, and Effort Requests on Beha. Journal of Labor Economics 20:923-51

Harris M, Raviv A. 1979. Optimal Incentive Contracts with Imperfect Information. Journal of Economic Theory 20:231-59

Hicks JR. 1932. The Theory of Wages: Macmillan

Holmstrom B, Milgrom P. 1991. Multitaks Principal-Agent Analyses: Incentive Contracts, Asset Ownership, and Job Design. Journal of Law, Economics, \& Organization 7:2452

Kagel JH, Owens MF. 2006. Minimum Wage Restrictions and Employee Effort in Labor Markets with Gift Exchange Present.

Kahn S. 1997. Evidence of Nominal Wage Stickiness from Microdata. The American Economic Review 87:993-1008

Kahneman D, Knetsch JL, Thaler R. 1986. Fairness as a Constraint on Profit Seeking: Entitlements in the Market. The American Economic Review 76:728-41

Kanemoto Y, MacLeod WB. 1992. The Ratchet Effect and the Market for Secondhand Workers. Journal of Labor Economics 10:85-98 
Katz L, Krueger A. 1991. The Effects of the New Minimum Wage in a Low-Wage Labor Market. In Proceedings of the Forty-Third Annual Meetings, Industrial Relations Research Association, pp. 254-65. Madison, WI

Katz LF, Krueger AB. 1992. The Effect of the Minimum Wage on the Fast-Food Industry. Industrial \& Labor Relations Review 46:6-21

Keynes JM. 1936. The General Theory of Employment, Interest and Money. London: Macmillan

Knoch D, Nitsche MA, Fischbacher U, Eisenegger C, Pascual-Leone A, Fehr E. 2007. Studying the Neurobiology of Social Interaction with Transcranial Direct Current Stimulation The Example of Punishing Unfairness. Cerebral Cortex

Knoch D, Pascual-Leone A, Meyer K, Treyer V, Fehr E. 2006. Diminishing Reciprocal Fairness by Disrupting the Right Prefrontal Cortex. Science 314:829-32

Kreps DM, Milgrom P, Roberts J, Wilson R. 1982. Rational cooperation in the finitely repeated prisoners' dilemma. Journal of Economic Theory 27:245-52

Krueger AB, Mas A. 2004. Strikes, Scabs, and Tread Separations: Labor Strife and the Production of Defective Bridgestone/Firestone Tires. Journal of Political Economy 112:253-89

Krueger AB, Summers LH. 1988. Efficiency Wages and the Inter-industry Wage Structure. Econometrica 56:259-93

Kube S, Maréchal MA, Puppe C. 2006. Putting Reciprocity to Work- Positive versus Negative Responses in the Field.

Kube S, Maréchal MA, Puppe C. 2008. The Currency of Reciprocity. Working Paper No. 377: Institute for Empiricial Research in Economics, University of Zurich

Laffont J-J, Tirole J. 1988. The Dynamics of Incentive Contracts. Econometrica 56:1153-75

Lazear E. 1986. Salaries and Piece Rates. Journal of Business 59:405-31

Ledyard J. 1995. Public Goods: A Survey of Experimental Research. In Handbook of Experimental Economics, ed. J Kagel, A Roth, pp. 111-94: Princeton University Press

Lee D, Rupp NG. 2007. Retracting a Gift: How Does Employee Effort Respond to Wage Reductions. Journal of Labor Economics 25:725-61

Levitt S, List JA. 2007. What do Laboratory Experiments Measuring Social Preferences tell us about the Real World. Journal of Economic Perspectives

List JA. 2006. The Behavioralist Meets the Market: Measuring Social Preferences and Reputation Effects in Actual Transactions. Journal of Political Economy 114:1-37

Livernash ER. 1957. The Internal Wage Structure. In New Concepts in Wage Determination, ed. GW Taylor, FC Pierson, pp. 143-72. New York: McGraw Hill

Machin S, Manning A. 1994. The Effects of Minimum Wages on Wage Dispersion and Employment. Industrial \& Labor Relations Review 47:319-29

MacLeod B, Parent D. 1999. Job Characteristics and the Form of Compensation. Research in Labor Economics 18:177-242

MacLeod BW. 2003. Optimal Contracting with Subjective Evaluation. American Economic Review 93:216-40

MacLeod WB, Malcomson JM. 1989. Implicit Contracts, Incentive Compatibility, and Involuntary Unemployment. Econometrica 57:447-80

MacLeod WB, Malcomson JM. 1993. Wage premiums and profit maximization in efficiency wage models. European Economic Review 37:1223-49

MacLeod WB, Malcomson JM. 1998. Motivation and Markets. American Economic Review 88:388-411

Malcomson J. 1999. Individual Employment Contracts. In Handbook of Labor Economics, ed. O Ashenfelter, D Card, pp. 2292-356. Amsterdam - New York: Elsevier

Malcomson JM. 1997. Contracts, Hold-Up, and Labor Markets. Journal of Economic Literature 35:1916-57 
Manning A. 2003. Monopsony in Motion: Imperfect Competition in Labor Markets: Princeton University Press

Manning A, Dickens R. 2002. The Impact of the National Minimum Wage on the Wage Distribution, Poverty and the Gender Pay Gap.

Maréchal M, Thöni C. 2007. Do Managers Reciprocate? Field Experimental Evidence from a Competitive Market. In SSRN eLibrary: SSRN

Marshall A. 1925. A Fair Rate of Wages. In Memorials of Alfred Marshall, ed. AC Pigou: Macmillan

Marshall A. 1969. Principles of Economics. London: Macmillan (Student Edition)

Mas A. 2006. Pay, Reference Points, and Police Performance. The Quarterly Journal of Economics 121:783-821

Mas A. 2008. Labor Unrest and the Quality of Production: Evidence from the Construction Equipment Resale Market. Review of Economic Studies 75:229-58

Mas A, Moretti E. 2008. Peers at Work. American Economic Review: in press

McLaughlin K. 1994. Rigid Wages? Journal of Monetary Economics 34:383-414

Naef M, Fehr E, Fischbacher U, Schupp J, Wagner G. 2008. Decomposing Trust - Explaining National and Ethnic Trust Differences. Institute for Empirical Research in Economics, University of Zurich

OECD. 1998. Employment Outlook, pp. 31-79: OECD

Offerman T. 2002. Hurting hurts more than helping helps. European Economic Review 46:1423-37

Oosterbeek H, Sloof R, van de Kuilen G. 2004. Cultural Differences in Ultimatum Game Experiments: Evidence from a Metaanalysis. Experimental Economics 7:171-88

Oreopoulos P, Wachter T, Heisz A. 2006. The Short- and Long-Term Career Effects of Graduating in a Recession: Hysteresis and Heterogeneity in the Market for College Graduates. NBER Working Papers, National Bureau of Economic Research

Padilla AJ, Bentolila S, Dolado JJ. 1996. Wage Bargaining in Industries with Market Power. Journal of Economics \& Management Strategy 5:535-64

Prendergast C. 1999. The Provision of Incentives in Firms. Journal of Economic Literature 37:7-63

Rabin M. 1993. Incorporating Fairness into Game Theory and Economics. American Economic Review 83:1281-302

Rees A. 1993. The Role of Fairness in Wage Determination. Journal of Labor Economics 11:243-52

Ross S. 1973. The Economic Theory of Agency: The Principal's Problem. American Economic Review 63:134-39

Roth AE. 1995. Introduction to Experimental Economics. The Handbook of Experimental Economics:3-109

Roth AE, Erev I. 1995. Learning in extensive-form games: Experimental data and simple dynamic models in the intermediate term. Games and Economic Behavior 8:164-212

Roth AE, Prasnikar V, Okuno-Fujiwara M, Zamir S. 1991. Bargaining and Market Behavior in Jerusalem, Ljubljana, Pittsburgh, and Tokyo: An Experimental Study. The American Economic Review 81:1068-95

Shafir E, Diamond P, Tversky A. 1997. Money Illusion. The Quarterly Journal of Economics 112:341-74

Shapiro C, Stiglitz JE. 1984. Equilibrium Unemployment as a Worker Discipline Device. The American Economic Review 74:433-44

Simon H. 1951. A Formal Theory of the Employment Relationship. Econometrica 19:293305

Slichter SH. 1920. Industry Morale. Quarterly Journal of Economics 35:36-60 
Slonim R, Roth AE. 1998. Learning in High Stakes Ultimatum Games: An Experiment in the Slovak Republic. Econometrica 66:569-96

Solon G, Barsky R, Parker JA. 1994. Measuring the Cyclicality of Real Wages: How Important Is Composition Bias? The Quarterly Journal of Economics 109:1-25

Tabibnia G, Lieberman MD. 2007. Fairness and cooperation are rewarding: evidence from social cognitive neuroscience. Ann N Y Acad Sci 1118:90-101

Teulings C, von Dieten L, Vogels E. 1998. Minimoomloon, arbeitdsmarkt en inkomensverdeling. Den Haag: Sdu Uitgevers

Teulings CN. 2003. The contribution of minimum wages to increasing wage inequality. Economic Journal 113:801-33

Treble J, van Gameren E, Bridges S, Barmby T. 2001. The Internal Economics of the Firm: Further Evidence from Personal Data. Labour Economics 8:531-52

Williamson O. 1975. Markets and Hierarchies: Analysis and Antitrust Implications. New York: Free Press

Wilson BA. 1999. Wage rigidity: a look inside the firm. Finance and Economics Discussion Series, Board of Governors of the Federal Reserve System (U.S.) 